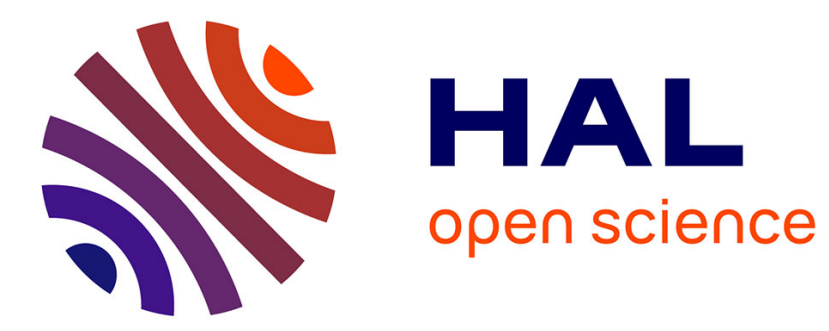

\title{
Considering the Arabian Neolithic through a reconstitution of interregional obsidian distribution patterns in the region
}

Lamya Khalidi, Marie-Louise Inizan, Bernard Gratuze, Rémy Crassard

\section{To cite this version:}

Lamya Khalidi, Marie-Louise Inizan, Bernard Gratuze, Rémy Crassard. Considering the Arabian Neolithic through a reconstitution of interregional obsidian distribution patterns in the region. Arabian Archaeology and Epigraphy, 2013, The Neolithic of Arabia - New Paradigms and Future Perspectives, 24 (1), pp.59-67. 10.1111/aae.12020 . hal-01828873

\section{HAL Id: hal-01828873 https://hal.science/hal-01828873}

Submitted on 4 Jul 2018

HAL is a multi-disciplinary open access archive for the deposit and dissemination of scientific research documents, whether they are published or not. The documents may come from teaching and research institutions in France or abroad, or from public or private research centers.
L'archive ouverte pluridisciplinaire HAL, est destinée au dépôt et à la diffusion de documents scientifiques de niveau recherche, publiés ou non, émanant des établissements d'enseignement et de recherche français ou étrangers, des laboratoires publics ou privés. 


\section{Considering the Arabian Neolithic through a reconstitution of interregional obsidian distribution patterns in the region}

As a result of a programme devoted to obsidian geochemical analyses for the Red Sea region (VAPOR), the register of analysed obsidian artefacts from Arabia has grown considerably in recent years. A percentage of these correspond to surveyed and excavated Neolithic contexts in Yemen, Saudi Arabia and Oman. This growing database of site to source matches has enabled us to consider the Neolithic of Arabia as more than just a period of sedentism and initial domestication, but as a period where we can begin piecing together the formulation of complex social networks and exchange mechanisms that included, and may even have depended to some extent on, mobile groups. Using obsidian source analyses coupled with spatial mapping, site and lithic data, we use obsidian as a guide to gain a better understanding of the early dynamics of interaction between regions in Arabia and beyond, and to assess what role the socio-economic networks identified may have had in the process of Arabian Neolithisation, or in certain cases, the lack thereof.

Keywords: South Arabia, Neolithic, obsidian sourcing, exchange mechanisms, lithic technology

\author{
Lamya Khalidi ${ }^{1}$, Marie-Louise \\ Inizan $^{2}$, Bernard Gratuze ${ }^{3}$, \\ Rémy Crassard ${ }^{1}$ \\ ${ }^{1}$ Archéorient, UMR $5133 \mathrm{du}$ \\ CNRS, Université Lyon 2, 7 rue \\ Raulin, 69007, Lyon, France \\ e-mail: lamya.khalidi@mom.fr; \\ remy.crassard@mom.fr \\ ${ }^{2}$ Maison de l'Archéologie et de \\ l'Ethnologie, UMR 7055 du \\ CNRS, Université de Nanterre, \\ 21 allée de l'Université, 92023, \\ Nanterre Cedex, France \\ e-mail: inizan@mae.u-paris10.fr \\ ${ }^{3}$ Institut de Recherche sur les \\ ArchéoMATériaux (IRAMAT), \\ UMR 5060 du CNRS, Université \\ d'Orléans, Centre Ernest- \\ Babelon, 3D rue de la Férollerie, \\ F-45071, Orléans Cedex, France \\ e-mail: gratuze@cnrs-orleans.fr
}

\section{Introduction}

\section{I.1. Preface}

For decades, Arabia has been regarded as peripheral to discussions of Neolithisation because the processes that occurred there in the early to mid-Holocene do not correspond to those of the classic Near Eastern model. In the Near East it is primarily the domestication of plants, and also that of animals, which is the major marker signalling the adoption of a Neolithic way of life. As archaeological research expands and more data is collected across Arabia and Africa, researchers in Arabia are moving further away from defining the Neolithic of these regions using the classic Near Eastern Neolithic criteria, and certainly in what concerns the quasi-dependence on agriculture. If defining a Neolithic depended on all these criteria being present, most regions would not have witnessed a Neolithic before historic times, if at all.

In the last three decades, it has become increasingly more common for archaeologists working in Arabia and sub-Saharan Africa to treat Neolithisation as a process that could include varied and co-existing social and economic trajectories, depending on the region. The models of Neolithisation that are emerging involve strategies of subsistence suited to specific regions, and ones that lead to complex social structures, food production and eventual domestication without the requirement of an agricultural way of life, per se (Brandt \& Carder 1987; Clark \& Brandt 1984; Cleuziou \& Tosi 1997; Crassard 2009; Fedele 1987 : 


\section{KHALIDI ET AL.}

35-38; 2009; Gutherz 2008; Marshall \& Hildebrand 2002; Joussaume 1995; Lesur 2007; Tosi 1986). It has become quite clear now that in those regions of Arabia where the climate and environment were not necessarily favourable for agriculture, it was often adopted belatedly, if at all, by most Neolithic communities.

In those landscapes where mobile and sedentary pastoral groups co-existed and thrived, however, complex exchange networks emerged quite early (see Ndiema, Dillian \& Braun 2010: 96). These Neolithic sites were not densely populated and had lower thresholds for settlement and population growth than their Near Eastern and Anatolian neighbours, despite their capacity to manage some surplus (early presence of storage vessels), and have sedentary lifestyles.

The issue we focus on in this paper is that of long-distance exchange as a phenomenon which develops alongside the first Neolithic societies in Arabia and signals the presence of complex social networks, some degree of economic management and technological change and the formalisation of inter-group relationships through developed channels of communication. We specifically look at the circulation of obsidian, a volcanic glass that exists in few regions of the world and was nonetheless used widely in prehistory for the production of sharp tools and elite objects. Its wide use meant that it was often exchanged at long distances from its origin, and that it circulated in far-reaching networks, possibly alongside other products of value (Inizan \& Francaviglia 1996; Francaviglia 1996). Using previously published results as a point of departure (Khalidi, Lewis \& Gratuze 2012; Khalidi et al. 2010; Khalidi 2009; Barca, Lucarini \& Fedele 2012), we present new data pertaining to obsidian geochemical analyses carried out as part of the Volcanological and Archaeological Program for Obsidian Research (VAPOR), on obsidian artefacts collected from Neolithic sites in Arabia by numerous projects.

Published obsidian geochemical analyses of artefacts concern obsidian recovered in the Tihamah coastal plain, the western escarpment (Khalidi 2007, 2008, 2011) and the highland plains in Yemen (Khalidi, Lewis \& Gratuze 2012; Lewis \& Khalidi 2008; Lewis et al. 2010), as well as previous results (Neolithic sites in the Hadramawt and in the eastern highlands, Yemen) that have been reassessed through a comparison to our updated geological database (Khalidi, Oppenheimer, Gratuze, Boucetta et al., 2010; Barca, Lucarini \& Fedele 2012). Apart from a summary of these results, this paper will concentrate on a discussion of the source of Yafa' in highland Yemen, which emerged as a major source of obsidian in Arabia, and on new obsidian source matches from three additional Neolithic sites in Arabia (Jebel Ghubayr, al-'Abr, and Mundafan) that have the potential to expand our view of the exchange networks in Arabia during the Neolithic (Fig. 1).

\section{I.2. Current state of obsidian research in Arabia and Africa: VAPOR}

The last five years have been dedicated to the building of an obsidian database for Arabia and Africa, in the context of a collaborative programme called VAPOR. This programme focuses on the systematic survey and sampling of sources of obsidian in Arabia and the Horn of Africa and their analysis mainly by Laser Ablation High-Resolution Inductively Coupled Plasma Mass-Spectrometry (LA-HR-ICP-MS). Results have allowed us to build an archaeological and analytical reference database that completely renews previous data, as well as bringing new information to light.

In the field in Yemen, we identified two unanalysed flows pertaining to the previously published obsidian sources of Jebel Lisi and Jebel Isbil (Francaviglia 1990a, $1990 \mathrm{~b}$ ) in the eastern highland plains, as well as four unknown sources in the western highland plains. Systematic sampling across flows was carried out to be able to define the widest range of geochemical compositions for each outcrop or volcanic complex. Thus far the Yafa' outcrop has the widest range of compositions, which we can confidently separate from other source compositions. Also distinguished are yet unlocalised Groups 1-4 that are compositionally related to those of Yafa' and are probably located in the vicinity of those Yafa' outcrops we have sampled (Khalidi, Lewis \& Gratuze 2012).

VAPOR has also been carrying out analyses on obsidian from hundreds of archaeological sites in Arabia, the Near East and the African Horn, a small percentage of which are certainly Neolithic in date. Our analyses have shown that in Arabia during the Neolithic period, the obsidian source of Yafa', located in the western highland plains of Yemen, provided most of the obsidian across the highlands, but also at long distance, with the material reaching the largest distances towards the eastern interior. Obsidian from the source of Jebel Lisi was also present on some sites in the highlands, although in smaller quantities. Highland Yemen obsidian has yet to appear beyond the western foothills (highlands), and only one example matching the source of Yafa' has been found so far in the Tihamah coastal plain. Thus far the compositions of all analysed Tihamah obsidian (except for the above sample) fall into the family of African 


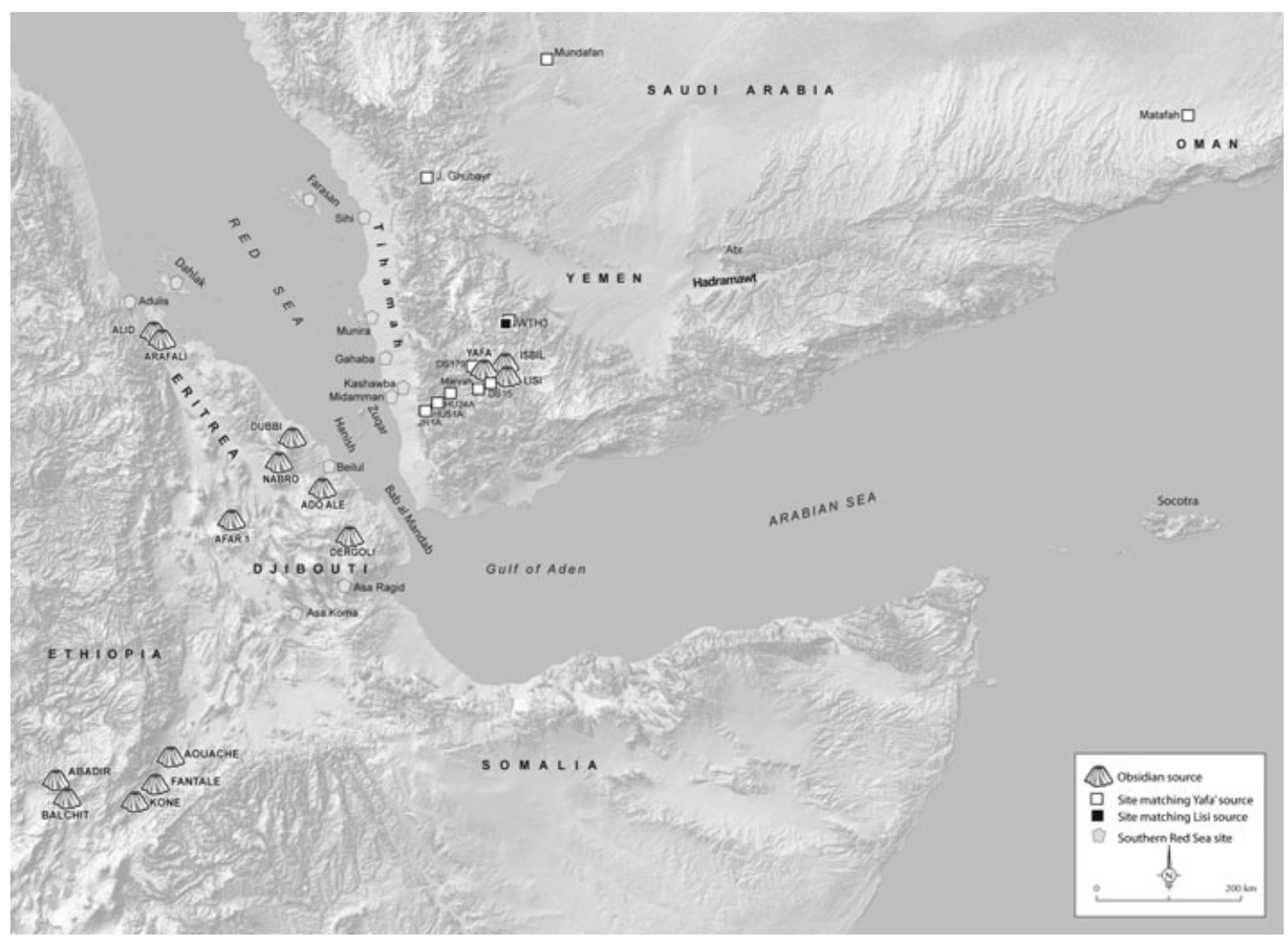

Fig. 1.

Map illustrating the sites and source outcrops mentioned in the text.

obsidian sources although there are yet to be exact matches. This reinforces other cultural evidence for cross-Red Sea contact and exchange between the Yemen and Horn of Africa coasts (Khalidi 2007, 2009; Khalidi, Oppenheimer, Gratuze, Boucetta et al., 2010).

\section{The Yafa' source and local highland obsidian distribution \\ II.1. Yafa'}

Geological and archaeological work along the Yafa' source outcrop included investigation of an extensive obsidian workshop area (DS179), previously documented by the Dhamar Survey Project (DSP) (Wilkinson, Edens \& Gibson 1997: 122). This workshop is probably one of a series located along the Yafa' obsidian flows, and for the time being remains unexcavated and undated. Upon a first assessment of non-lithic surface collections (ceramics, stone architecture), DS179 appears to be Bronze Age to Himyarite in age, but it is likely that the area of the site, rich in cortical nodules with volumes favourable for the extraction of lamellar products, was in use much earlier. A large number of the lithics recovered are single-platform bladelet cores on cortical nodules of the type found in abundance across the site (Fig. 2). Most of the debitage and waste recovered are cortical or pertain to the bladelet core preparation and reduction sequences suggested by the cores (Fig. 3). Our investigation of surface finds revealed that no cores were exhausted, and that many were abandoned after only a few removals, likely due to the abundance of nodules on the site. Most cores recovered had cortical platforms that needed little to no preparation (Fig. 2/a), and all were exploited using a direct percussion technique.

While this workshop site remains undated, it is likely to have been a knapping area in the Neolithic and to have been eclipsed by later occupations. Planned future surveys and excavations will reveal its date and whether or not more important Neolithic obsidian workshops existed in the vicinity. To date, DS179 is the only extensive bladelet workshop found along an obsidian source in Yemen, and it is no surprise that it was discovered along the Yafa' flows from which highland Neolithic populations were intensively exchanging obsidian across the highlands and at long distance across Arabia, in much smaller quantities. 


\section{KHALIDI ET AL.}
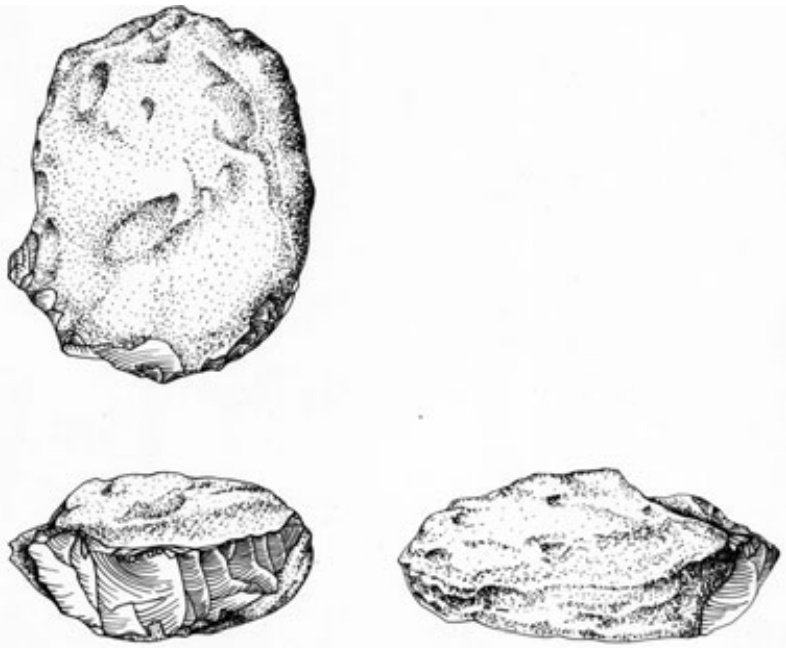

a

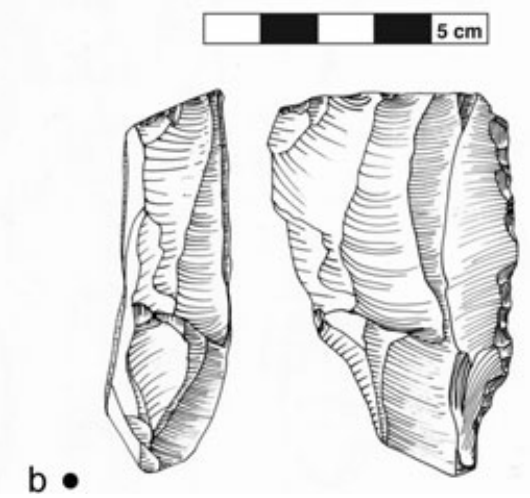

Fig. 2.

Illustration of two obsidian cores collected on the surface of site DS179 on the Yafa' obsidian source.

\section{II.2. Central and western highlands}

The results of analyses of thirty-nine obsidian artefacts from nine DSP sites with Neolithic components located in the highland source zone (Dhamar/Rada' highland plains; two stratified) demonstrate that $59 \%$ of the archaeological obsidian collected matches the Yafa' source, and 21\% matches the Yafa' Region ${ }^{1}$ sources. The remaining $23 \%$ of archaeological obsidian matches the Group 5 source which has afinities to the Jebel Lisi outcrop (Khalidi, Lewis \& Gratuze 2012: 152).

\section{II.3. Eastern highlands}

The data provided in Barca, Lucarini and Fedele's recent publication (2012) clearly demonstrate that local Neolithic

1 Yafa' Region includes the minor sources of Maryah, Jibjibiyyah and Jirab al-Suf, and Groups 1-4 which relate to the Yafa' source.
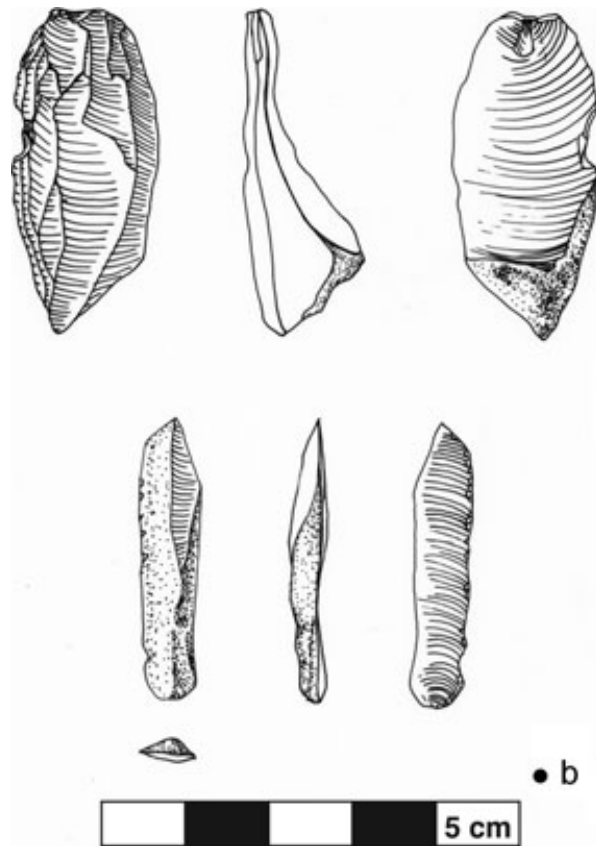

Fig. 3 .

Illustration of two obsidian cortical lamellar products collected on the surface of site DS179 on the Yafa' obsidian source.

obsidian networks extended to sites in the Khawlan eastern highlands. The Wadi ath-Thayillah 3 site is an aceramic Neolithic open-air settlement consisting of stone elliptical structures, and a fauna of which $89 \%$ are domesticates (2012: 606). The site was occupied between the sixth and fourth millennia $\mathrm{BC}$ and is located in the eastern highlands with access to natural passages to the desert interior. Twenty obsidian artefacts from the Wadi ath-Thayyilah 3 excavations were analysed and compared to our geochemical obsidian source database (Khalidi et al. 2010). Of these, $70 \%(n=14)$ match the Yafa' source and $30 \%(\mathrm{n}=6)$ match the Jebel Lisi source (Barca, Lucarini \& Fedele 2012: 618).

\section{II.4. Local highland networks}

In a recent article, spatial mapping of site to Yafa' source matches in the highlands revealed an evident north-south corridor that was in use from the Neolithic to the early Islamic period, and along which obsidian appears to have circulated with more intensity than along other avenues (Khalidi, Lewis \& Gratuze 2012: 154). A highland eastern corridor is becoming clearer with further analyses of obsidian from the eastern highlands (Barca, Lucarini \& Fedele 2012; Khalidi et al. 2010: 2339), which show Yafa' as being the major supplier of obsidian during the 
Neolithic period followed by Jebel Lisi and its Group 5 relative.

Between the sixth and fourth millennia BC, some Neolithic populations in the central highlands lived in permanent settlements with domesticated herds (Barca, Lucarini \& Fedele 2012: 606; Fedele 2009: 223) while others were mobile groups. We have shown that groups taking part in either strategy were engaged in obsidian exchange. Within this context, some degree of resource and territorial management is expected, as is the formalisation of natural corridors of movement from one region to the next, like that of the north-south corridor through the highland plains. Recent analyses of material from excavated Neolithic period contexts in Saada extend this corridor of movement to the northern highlands of Yemen and beyond.

\section{North of Yafa': Saada and Najran}

Recent geochemical analyses were conducted on obsidian artefacts from the sites of Jebel Ghubayr $(\mathrm{n}=6)$ and Mundafan $(\mathrm{n}=3)$ located in northern Yemen and Najran, Saudi Arabia, respectively. These analyses confirm that the obsidian found on these sites matches the Yafa' outcrop. In this case the distance between source and sites is between 300 and $500 \mathrm{~km}$ as the crow flies.

\section{III.1. Northern Yemen highlands (Saada region)}

Jebel Ghubayr is located in the northern Saada province of Yemen and is a rock shelter with engraved animal reliefs along its walls. This site was surveyed by M. Garcia and M. Rachad in 1992 (Garcia \& Rachad 1997; Inizan \& Rachad 2007) and consisted of in situ deposits that included the remains of hearth structures, lithic material and faunal remains (Inizan 2007: 67). No soundings were carried out and the material was recovered from the surface of the site. A number of tools and waste, of which forty were obsidian fragments, were collected from the site. The obsidian material included one cortical end scraper, bladelet fragments and flakes (Inizan 2007: fig. $34 / 4,8,9)$. The most characteristic tools recovered were bifacially worked points and end scrapers, most from flint material (2007: fig. 33). No obsidian/flint cores or core trimming products were found on the surface, suggesting that knapping took place away from the shelter.

Although the site is not dated, it has been interpreted as a rock shelter occupied during the Neolithic period but associated with hunters. This period designation is by no means certain but is based on the wild animal species (predominantly wild equids) represented on the associated shelter walls and the typo-technological characteristics of the lithic toolkit, specifically the bifacially flaked projectile points of the tanged and winged variety that can be dated to as early as the seventh millennium BC (Crassard 2008) or between 6500 and $4500 \mathrm{BC}$ based on the presence of a single trihedral point (Charpentier 2008; Inizan 2007).

The six obsidian artefacts analysed include cortical flakes and bladelets (Fig. 4). Four of these match the source of Yafa' and two of these belong to Group 5 (Figs 5 \& 6) which remains unidentified but is related to the Jebel Lisi source in Yemen.

\section{III.2. Saudi Empty Quarter: southern Saudi Arabia}

Slightly further north-east of Saada, along the Holocene margins of the Mundafan palaeolake in the Empty Quarter (Najran province) of Saudi Arabia, three obsidian artefacts (Fig. 4) were collected from the surface of the site of Mundafan-20 (Crassard et al., forthcoming). The site, which has an estimated date of seventh-sixth millennium $\mathrm{BC}$, is interpreted as a temporary or seasonal hunting site by the authors. The three obsidian artefacts analysed, which include one bladelet fragment and two flakes, match the source of Yafa' in highland Yemen (Figs 5 \& 6). Crassard et al. (forthcoming) interpret the lithic industry at Mundafan as belonging to different cultural facies than those defined for Yemen, Oman and the UAE.

\section{III.3. Discussion of northerly networks}

Both the sites of MDF-20 and Jebel Ghubayr are probably seasonal sites with lithic industries that suggest that hunting activities (projectile points) and the treatment of hides (end scrapers) were carried out on or near the site. The environmental (palaeolake margin, rock shelter) and cultural contexts (wild equid reliefs) of both sites further suggest that wild animal resources would have attracted populations during the early to mid-Holocene. Furthermore, they are both supplied with obsidian from the same source (Yafa') at hundreds of kilometres distance to the north-north-east of the source. These data are the first to support the theory that mobile groups were engaged in the circulation of obsidian from the Yafa' outcrop. The implications are that in the Neolithic, obsidian circulated in relatively large amounts (Jebel Ghubayr $n=40$ ) throughout the highlands, even at significant distances, but witnessed a substantial drop-off as they moved away from the highland centre to the lowland desert interior (Mundafan $\mathrm{n}=3$ ). Moreover, there is a clear participation of mobile or partially mobile groups in this circulation. 


\section{KHALIDI ET AL.}

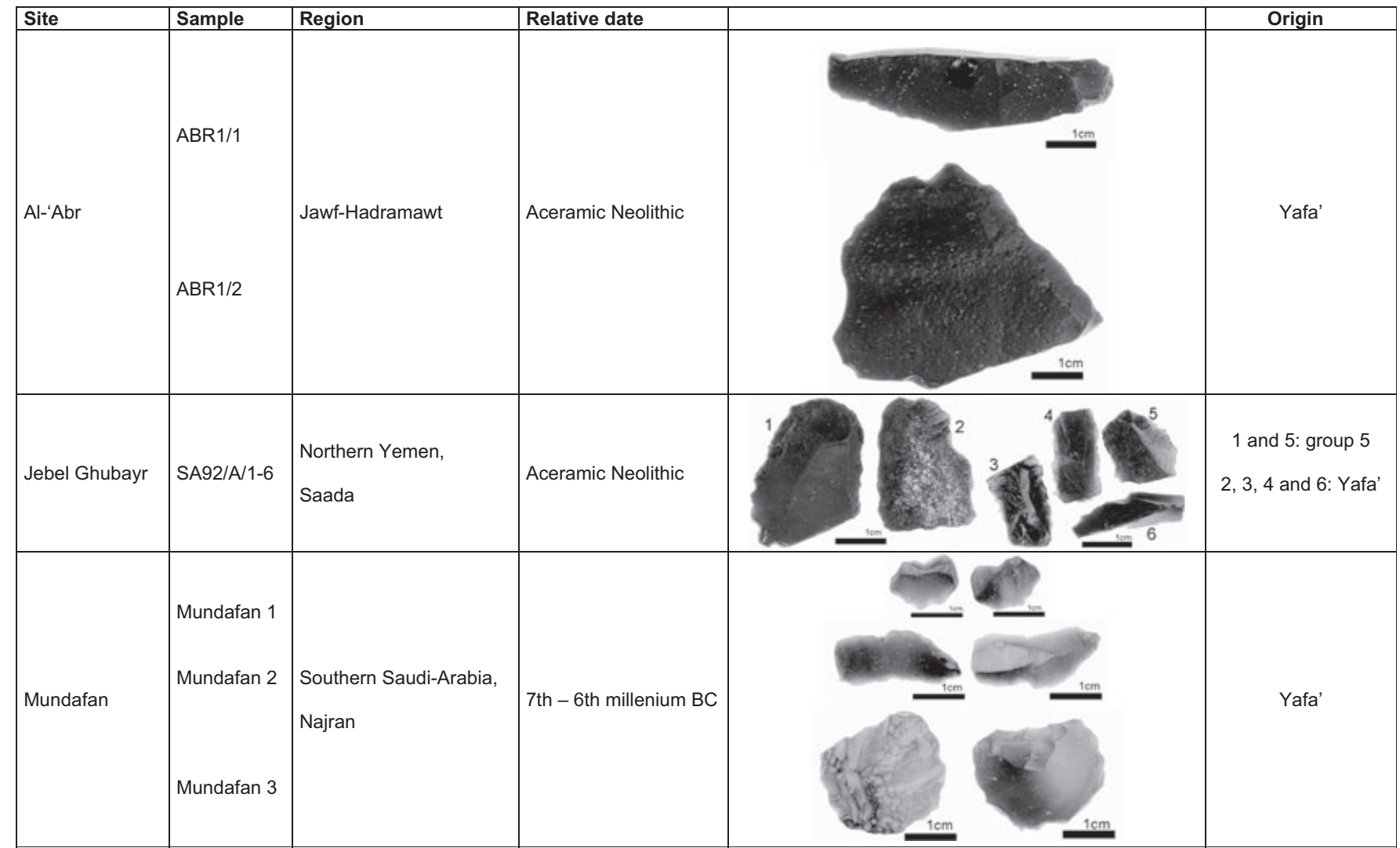

Fig. 4 .

Table of descriptions and photographs of the analysed obsidian artefacts from the sites of Jebel Ghubayr, Mundafan and al-'Abr.
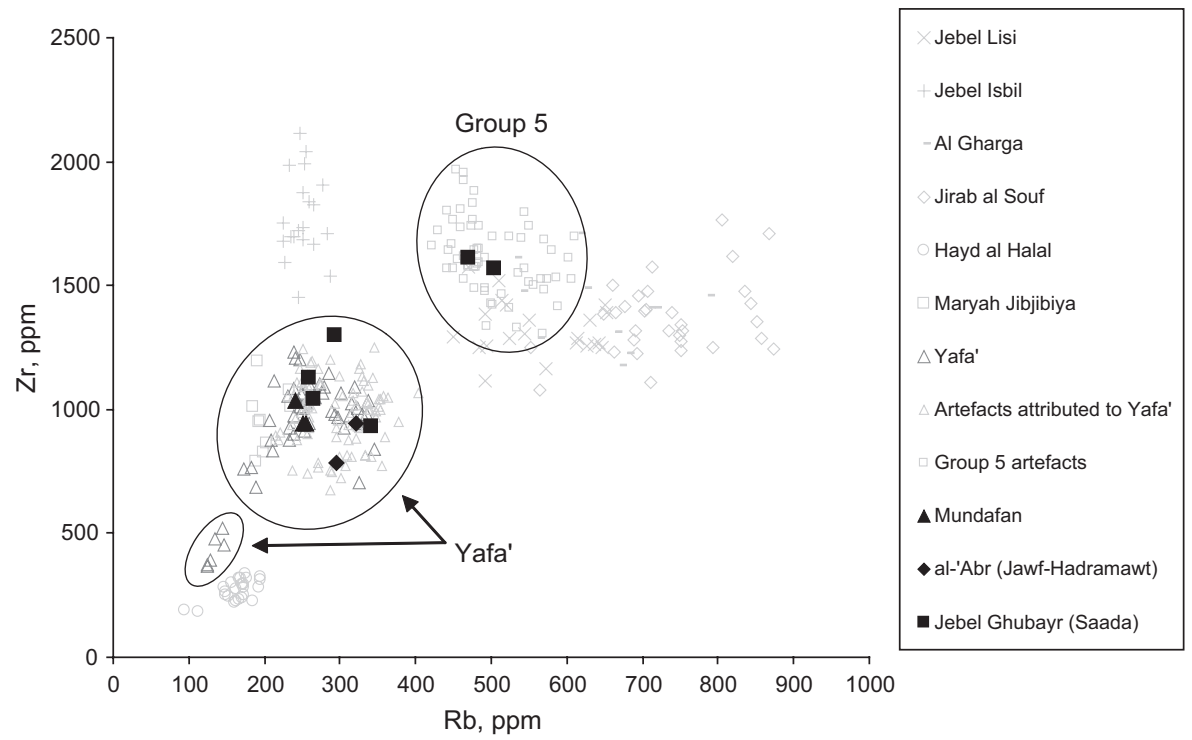

Fig. 5 .

Diagram Rb/Zr of the al-'Abr, Jebel Ghubayr and Mundafan obsidian artefact compositions in relation to the Yemen highland obsidian source compositions and to other artefacts related to Yafa' and Group 5 analysed to date. 


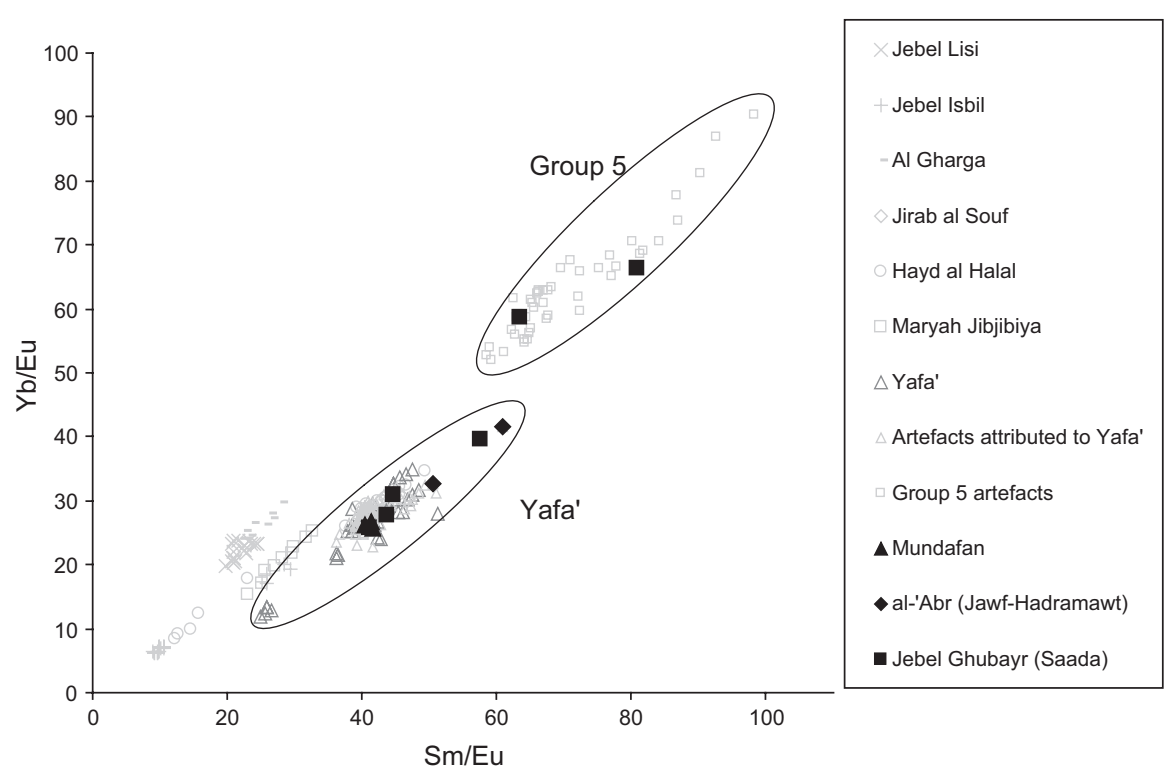

Fig. 6 .

Diagram $\mathrm{Yb} / \mathrm{Eu}-\mathrm{Sm} / \mathrm{Eu}$ of the al-'Abr, Jebel Ghubayr and Mundafan obsidian artefact compositions in relation to the Yemen highland source compositions and to other artefacts related to Yafa' and Group 5 analysed to date.

\section{East of Yafa': Hadramawt and Dhofar}

Published results have shown that obsidian from the Neolithic site of Wadi Matafah, located in Omani Dhofar, matches the source of Yafa' (Khalidi et al. 2010: 2339). This site is located at an estimated $1000 \mathrm{~km}$ from the source as the crow flies. New geochemical analyses of obsidian $(n=2)$ collected on the surface of the Neolithic site of al-'Abr 1 in the Jawf-Hadramawt by M-L. Inizan in 1993, were recently carried out and add to our knowledge of Yafa' obsidian circulation towards eastern Arabia. Both obsidian artefacts match the source of Yafa' in the western highland plains. These include two obsidian flakes, one of which is cortical (see Fig. 4). The site of al-'Abr is located at an estimated $350 \mathrm{~km}$ east-north-east of the source zone in the lowland desert interior. If we add the site of Mundafan to the picture, we can posit that the desert interior had its own networks through which smaller amounts of materials moved. The sites of $\mathrm{Al}$ 'Abr and Matafah are on two ends of the major Hadramawt river valley. The Jawf-Hadramawt palaeoriver certainly acted as a corridor suitable for human mobility as well as settlement in the early to mid-Holocene. Mundafan is located along one of many Holocene palaeolakes that dotted what is now the arid desertscape of the Arabian interior. This palaeolake is likely to have served as a stopping point for mobile or partially mobile groups. The picture we can begin to draw is one of a region that was possible to traverse, dotted with watering holes ideal for seasonal settlement or itinerant stops, and riverine systems that acted as corridors to far-reaching areas like that of Dhofar in Oman. While the archaeological record remains incomplete in terms of what actual settlement patterns may have looked like in the early to midHolocene, we can begin to see that the role of mobile groups was a key factor in the movement of obsidian at such long distances.

\section{Discussion: Afro-Arabian and inter-Arabian networks}

Except in the case of the Tihamah coastal plain (Red Sea coast) where a substantial amount of obsidian arrived from East Africa (Khalidi, Oppenheimer, Gratuze, Boucetta et al., 2010), there is a significant drop-off in the amounts of obsidian found on non-highland Arabian Neolithic sites. The fluidity of the highland obsidian network is interrupted once the geography changes. One could point to differences in subsistence strategies or distance, but both the sites of Jebel Ghubayr in the northern Yemen highlands and Mundafan in the Saudi Arabian desert are thought to pertain to groups of seasonal hunters and are at large distances from the source outcrops supplying them without taking elevation into account. As regards obsidian circulation, it is possible that the importance of the subsistence strategy of a group (specifically of mobile 


\section{KHALIDI ET AL.}

groups) came into play where the redistribution of this material towards the eastern Arabian interior was concerned, with seasonal mobile groups moving the material with them and trading small amounts for needed goods. A better understanding of the modes of co-existence and codependence of settled pastoralists or agriculturalists and seasonal or mobile groups, which occurred in the Holocene in Arabia, is crucial for understanding both the circulation of goods across extreme terrain and over long distances and the process of Neolithisation in Arabia. It is likely that this process was partially affected by groups being exposed to one another and being linked by an intensification of exchange. As for new studies emerging on the Neolithic of East Africa, the Neolithic of Arabia cannot be discussed without an understanding of the life ways of non-sedentary groups and their relationship to sedentary communities. Obsidian research has proved to be an invaluable tool for understanding such relationships in Arabia and the development of such data is certain to reveal the complex nature of exchange networks in the context of a different kind of Neolithic.

\section{Acknowledgements}

We would like to acknowledge M. Rachad (University of Dhamar, Yemen) whose work on the prehistory of Saada made these new analyses possible. The analyses were funded by a Plan Pluri-Formation entitled « CODAI Archéomatériaux inorganiques " (IRAMAT- Université d'Orléans - UTBM, CEPAM - Université de Nice SophiaAntipolis, CRAHM - Université de Caen, CAA - Université de Rennes). It is thanks to Didier Binder and the CEPAM that our participation in this collaborative program was made possible. This article benefitted from the comments of two anonymous reviewers. [Note: Correction added on 13 May 2013 after initial publication on 30 April 2013: further details on funding received by authors have been added to the acknowledgements.]

\section{References}

Barca, D., Lucarini, G. \& Fedele, F.G. 2012. Provenance of Obsidian Artefacts from the Wādõ Ath-Thayyilah 3 Neolithic Site (Eastern Yemen Plateau) by LA-ICP-MS Method. Archaeometry: 603-622.

Brandt, S.A. \& Carder, N. 1987. Pastoral rock art in the Horn of Africa: making sense of udder chaos. World Archaeology 19/2: 194 -213 .

Charpentier, V. 2008. Hunter-gatherers of the 'empty quarter of the early Holocene' to the last Neolithic societies: chronology of the late prehistory of south-eastern Arabia (8000-3100 BC). PSAS 38: 93 116.

Clark, J.D. \& Brandt, S.A. eds. 1984. From Hunters to Farmers: The Causes and Consequences of Food Production in Africa. Berkley/Los Angeles: University of California Press.

Cleuziou, S. \& Tosi, M. 1997. Hommes, climats et environnements de la péninsule Arabique à l'Holocène. Paléorient 23/2: 121-136.

Crassard, R. 2008. La préhistoire du Yémen: Diffusions et diversités locales, à travers l'étude d'industries lithiques du Hadramawt. (BAR S1842). Oxford: Archaeopress.

Crassard, R. 2009. Modalities and characteristics of human occupations in
Yemen during the Early/Mid-Holocene. Comptes Rendus Geosciences 341/8-9: 713-725.

Crassard, R., Petraglia, M.D., Drake, N. \& Breeze, P. et al. forthcoming. Middle Palaeolithic and Neolithic occupations around Mundafan palaeolake, southern Saudi Arabia: implications for climate change and human dispersals.

Fedele, F.G. 1987. Die Jungsteinzeit in Nordjemen. Pages 35-38 in Daum M. (ed.), Jemen. 3000 Jahre Kunst und Kultur des glücklichen Arabien (Innsbruck, Pinguin-Verlagm/Frankfurt, UmschauVerlag).

Fedele, F.G. 2009. Early Holocene in the Highlands: Data on the Peopling of the Eastern Yemen Plateau, with a Note on the Pleistocene Evidence. Pages 215-236 in Petraglia M.D. \&Rose J.I. (eds.), The Evolution of Human Populations in Arabia: Paleoenvironments, Prehistory and Genetics (Paleobiology and Paleoanthropology) (New York, Springer Science+Business Media B.V.).

Francaviglia, V.M. 1990a. Obsidian sources in ancient Yemen. Pages 129-136 in de Maigret, A. (ed.), The Bronze Age Culture of Khawlan at-Tiyal and al-Hada (Yemen Arab Republic), (IsMEO Reports and Memoirs vol. XXIV) (Rome, IsMEO).
Francaviglia, V.M. 1990b. Les gisements d'obsidienne hyperalcaline dans l'Ancien Monde: étude comparative. Revue d'Archéométrie 14: 43-64.

Francaviglia, V.M. 1996. Il existait déjà au Néolithique un commerce d'obsidienne à travers la mer Rouge. Pages 65-70 in L'Archéométrie dans les pays Européens de langue latine et l'implication de l'archéométrie dans les grands travaux de sauvetage archéologique. Actes du colloque d'Archéométrie 1995, Périgueux (Supplément à la Revue Archéométrie) (Périgueux, Pole Editorial Archéologique de l'Ouest [P.E.A.O.]).

Garcia, M.A. \& Rachad, M. 1997. L'art des origines au Yemen. Paris: Le Seuil.

Gutherz, X. 2008. Aux origines de la production dans la Corne de l'Afrique: un champ d'étude à reconquérir. Pages 127151 in Archéologies de Provence et d'ailleurs: Mélanges offerts à Gaëtan Congès et Gérard Sauzade, vol. B.A.P. (Supplément 5) (Aix-en-Provence, Éditions de l'APA).

Inizan, M.-L. 2007. Des occupations préhistoriques à Saada. Pages 61-72 in Inizan, M-L. \& Rachad, M (eds.), Art rupestre et peuplements préhistoriques au Yémen (Sanaa, CEFAS). 


\section{CONSIDERING THE ARABIAN NEOLITHIC}

Inizan, M.-L. \& Francaviglia, V.M. 2002. Les périples de l'obsidienne à travers la mer Rouge. Journal des Africanistes 72/2: 1119.

Inizan, M-L. \& Rachad, M. eds. 2007. Art rupestre et peuplements préhistorique au Yémen. Sanaa: CEFAS.

Joussaume, R. 1995. Les premières sociétés de production. Pages 15-63 in Joussaume, R. (ed.), Tiya-l'Éthiopie des Mégalithes: Du biface à l'art rupestre dans la Corne de l'Afrique (Poitiers, P. Oudin).

Khalidi, L. 2007. The formation of a southern Red Seascape in the late prehistoric period: Tracing cross-Red Sea culturecontact, interaction, and maritime communities along the Tihamah coastal plain, Yemen in the third to first millennium BC. Pages 35-43 in Starkey, J., Starkey, P. \& Wilkinson, T. (eds.), Natural Resources and Cultural Connections of the Red Sea: Proceedings of Red Sea Project III (Society for Arabian Studies Monographs No. 5 and BAR International Series 1661) (Oxford, Archaeopress).

Khalidi, L. 2008. The late prehistoric standing stones of the Tihâma (Yemen): the domestication of space and the construction of human-landscape identity. Revue des Mondes Musulmans et de la
Méditerranée (REMMM): Yémen, territoires et identités 121-122: 17-33.

Khalidi, L. 2009. Holocene Obsidian Exchange in the Red Sea Region. Pages 279-291 in Petraglia, D.\& Rose, J.I. (eds.), The Evolution of Human Populations in Arabia:

Paleoenvironments, Prehistory and Genetics (Vertebrate Paleobiology and Paleoanthropology) (New York, Springer Science+Business Media B.V.).

Khalidi, L. 2011. The reconstruction of an Arabian cultural landscape through the study of the dynamics of obsidian exchange during the Holocene. Annales de la Fondation Fyssen 25: 40-50.

Khalidi, L., Lewis, K. \& Gratuze, B. 2012. New perspectives on regional and interregional obsidian circulation in prehistoric and early historic Arabia. PSAS 42: 1-22.

Khalidi, L., Oppenheimer, C., Gratuze, B., Boucetta, S. et al. 2010. Obsidian sources in highland Yemen and their relevance to archaeological research in the Red Sea region. Journal of Archaeological Science 37: 2332-2345.

Lesur, J. 2007. Chasse et élevage dans la Corne de l'Afrique entre le Néolithique et les temps historiques. (Cambridge Monographs in African Archaeology 68,
BAR International Series 1602). Oxford: Archaeopress.

Lewis, K. \& Khalidi, L. 2008. From prehistoric landscapes to urban sprawl: the Mașna at Māryah region of highland Yemen. PSAS 38: 215-230.

Lewis, K., Khalidi, L., Eisenberger, B. \& Sanabani, A. 2010. Mapping Mașna 'at Māryah: using GIS to reconstruct the development of a multi-period site in the highlands of Yemen. PSAS 40: 213-226.

Marshall, F. \& E., Hildebrand 2002. Cattle Before Crops: The Beginnings of Food Production in Africa. Journal of World Prehistory 16/2: 99-143.

Ndiema, E., Dillian, C.D. \& Braun, D.R. 2010. Interaction and Exchange Across the Transition to Pastoralism, Lake Turkana, Kenya. Pages 95-110 in Dillian C.D. \& White C.L. (eds.), Trade and Exchange: Archaeological Studies from History and Prehistory (New York, Springer).

Tosi, M. 1986. The Emerging Picture of Prehistoric Arabia. Annual Review of Anthropology 15: 461-490.

Wilkinson, T.J., Edens, C. \& Gibson, M. 1997. The Archaeology of the Yemen High Plains: A preliminary chronology. $A A E$ 8: 99-142. 